\title{
Factors Associated with Common Mental Disorders in Truck Drivers
}

\author{
Michelle Engers Taube de Oliveira* (1) \& Mary Sandra Carlotto (1) \\ Universidade do Vale do Rio dos Sinos, São Leopoldo, RS, Brasil
}

\begin{abstract}
This study aimed to identify the risk factors of Common Mental Disorders (CMD) using a sample of 565 Brazilian truck drivers. For data capture were applied the Self-Reporting Questionnaire (SRQ-20), Scale subscale of Psychosocial risks and questionnaire with socio-demographic, working and occupational stressors. The results obtained by multivariate binary logistic regression analysis, have explained the $39.9 \%$ of variation on CMD. The occupational stressor working hours is the predictor variable with highest impact, may implying in an increase of 5.41 times more chance of the trucker to present CMD. The results indicate actions by management level as work organization and public authorities with regard to the external work conditions.
\end{abstract}

KEYWORDS: common mental disorders, truck drivers, occupational health, risk factors, occupational stressors, multivariate binary logistic regression analysis

\section{Fatores Associados aos Transtornos Mentais Comuns em Caminhoneiros}

\begin{abstract}
RESUMO - Este estudo objetivou identificar os fatores de risco dos Transtornos Mentais Comuns (TMC) em uma amostra de 565 caminhoneiros brasileiros. Para a coleta de dados, foram utilizados o Self-Reporting Questionnaire (SRQ-20), Subescalas da Escala de Riscos Psicossociais e questionários sociodemográfico, laboral e de estressores ocupacionais. Os resultados obtidos por meio da análise de Regressão Logística Binária Multivariada explicaram 39,9\% das variações dos TMC. A variável preditora de maior impacto foi o estressor ocupacional jornada de trabalho que implicou em um aumento de 5,41 vezes mais chance do caminhoneiro apresentar TMC. Os resultados sugerem ações por parte dos gestores quanto à organização do trabalho e por parte do poder público no que diz respeito às condições externas de trabalho.
\end{abstract}

PALAVRAS-CHAVE: transtornos mentais comuns, caminhoneiros, saúde ocupacional, fatores de risco, estressores ocupacionais, análise de regressão logística binária multivariada

Common Mental Disorders (CMD) are classified as a picture non-psychotic and multidimensional of psychic suffering, because the coexistence of various symptoms and it constitutes a group of frequent mental health problems in the population, causing suffering and functional impairment (Goldberg \& Huxley, 1992). The authors define CMD as somatoform, anxiety and depression disorders, including the symptoms of insomnia, fatigue, exhaustion, neglect, decreased libido, loss of appetite, depressed mood, irritability, forgetfulness, difficulty on concentrating, somatic and nonspecific complaints.

CMDs cause considerable losses in the functioning and health of the individual (World Health Organization [WHO],
2017) and indicate a high probability of absenteeism in work activities and reduced productivity (Reichenheim et al., 2014; WHO, 2017), representing a high social and economic cost (Fonseca \& Carlotto, 2011; Goldberg \& Huxley, 1992; Ludermir \& Melo Filho, 2002). Early identification of CMDs in workers can prevent long-term leaves and reduce costs (Stansfeld et al., 2011).

The number of people with CMD is increasing considerably in low-income countries due to population growth and increased life expectancy (Nunes et al., 2016; WHO, 2017). CMD may be associated with demographic characteristics, living conditions, work structure (Ludermir \& Melo Filho, 2002) and occupational stressors (Carlotto

\footnotetext{
*E-mail: michelletaube@hotmail.com

- Submetido: 21/03/2018; Aceito: 23/11/2018.
} 
et al., 2015; Carlotto \& Câmara, 2015; Fonseca \& Carlotto, 2011). They are widely investigated in workers because they cause absenteeism, inability to work and early retirement and can be considered a public health problem, due to the high prevalences found (Silva-Junior \& Fischer, 2014).

In Brazil, investigations reveal that its prevalence has been associated with females (Carlotto et al., 2015; Nunes et al., 2016; Rodriguez-Lopez et al., 2016; Silva et al., 2017), younger age (Carlotto \& Câmara, 2015; Nunes et al., 2016), black race, separated or widowed marital status, low education (Ludermir \& Melo Filho, 2002; Nunes et al., 2016) and income (Nunes et al., 2016; Silva et al., 2017).

Notoriously, the work context often undergoes several changes. In this case, the professional category of truck driver has undergone significant changes since 2012. This profession, is characterized by long working hours, high demands on meeting deadlines, with no rest breaks, irregular working hours, night work shifts, unhealthy eating habits (Alessi \& Alves, 2015; Apostolopoulos et al., 2016; Cavagioni et al., 2009; Van der Beek, 2012), high consumption of alcohol drinks and sleep inhibiting drugs and the high rate of traffic accidents (Mir et al., 2012) began to be governed by a specific law, aimed at improving the working conditions of these professionals.

The changes began with the implementation of the Driver Law, 12.619, in 2012, and in 2015, in a new version, Law 13.103. This statute provides flexible working hours (up to 12 hours), staging points, meal times, interstitial, overtime and waiting hours. The toxicological examination was also included in the renewal of the National Driver's License (NDL), admission and dismissal when employed, thus establishing a new relationship of the truck driver with his work, which was previously governed by Article 62 of the Consolidação das Leis Trabalhistas (Consolidation of Labor Laws), which did not provide the setting of working hours.

The activity of driving truck was associated with symptoms of stress, anxiety, burnout syndrome, psychological distress, substance abuse, depression and other psychiatric disorders (Apostolopoulos et al., 2010). Krueger (2013) refers that the professional occupation of the truck driver is detrimental to the welfare of these workers, due to the way the work is constituted and organized.
Studies conducted with this population showed a variation in the prevalence from $6.1 \%$ (Ulhôa et al., 2010) to $33 \%$ (Cavagioni et al., 2009) of CMD. The factors associated with CMD in the study of Ulhôa et al. (2010) were the high psychological demand, the low social support and the long workday stressor. Symptoms like referring tiredness, concentration decreased, consider themselves stressed, having personal or work problems and carrying cargos in which the pressure of deadline is constant were the factors associated with CMD in the study of Cavagioni et al. (2009).

Studies indicate that the organization of road transport can affect the mental health of these workers (Bigelow et al., 2014; Lemke et al., 2015; Van der Beek, 2012). Considering that environmental factors are responsible for CMD (Goldberg \& Huxley, 1992), it is indispensable to the analysis of this worker's labor work context to understand and avoid getting ill (Apostolopoulos et al., 2016; Shattell et al., 2010; Van der Beek, 2012).

Transport modal can be considered a vulnerable and high-risk segment, considering the nature of the work's organization (Apostolopoulos et al., 2016; Lemke et al., 2015). Long journeys, road conditions, the few places available for these workers to feed and perform their personal hygiene, the distance from their family and the responsibility in traffic and whit equipment reveal the working conditions of these professionals (Bigelow et al., 2014; Delfino \& Moraes, 2015; Lemke et al., 2015; Ulhôa et al., 2010).

Considering that there are 2,645,992 truck drivers operating in the Brazilian territory, moving about $61.1 \%$ of the cargo transported in the country (National Transport Confederation [NTC], 2016) and that their physical and mental health is important for the safety of the population on the roads (Apostolopoulos et al., 2016), it is necessary to broaden the understanding about the working conditions to which truck drivers are exposed, as well as to identify the risks and stressors present in the work practice, which predict the affecting of CMD. By the foregoing, this cross-sectional observational, analytical study aims to identify sociodemographic, working, psychosocial risks and occupational stressors factors associated with CMD in truck drivers.

\section{METHODS}

\section{Participants}

The non-probabilistic sample was composed by 565 Brazilian truck drivers in professional practice for more than four months, the impact time of stressors on health, according to a longitudinal study carried out by Schonfeld (1996). The selection criterion was male, which predominates with $99.8 \%$ in the profession (NTC, 2016), having a National Driver's License (NDL) of category "C" or "E", modalities required by the truck driver professional.

Most of the 565 participants had a steady mate $(86.2 \%$, $\mathrm{n}=487)$; children $(77.2 \%, \mathrm{n}=436)$; and schooling at high school level $(52.9 \%, \mathrm{n}=299)$. The average age was 37.7 years old $(\mathrm{SD}=9.44$, range $=20$ to 71$)$ and average salary of $\mathrm{R} \$$ $2.808,38(\mathrm{SD}=1105.22$, range $=1.000$ to 15.000$)$. 
Regarding work characteristics, most of them maintained employment relationship $(85.8 \%, \mathrm{n}=485)$, traveled without a company $(89.2 \%, \mathrm{n}=504)$ and had, on average, 11.7 years of professional experience $(\mathrm{SD}=9.5$, range $=1$ to 45$)$. Participants worked, on average, 24 days a month $(\mathrm{SD}=2.34$, range $=15$ to 30 ) and the average daily workload was 12 hours $(\mathrm{SD}=2.41$, range $=5$ to 18$)$.

As to the type of route, $54.2 \%(n=306)$ they traveled small stretches of road, not staying overnight on the road for work - short route; $14.2 \%(n=84)$ worked two to six days on the road - average route; and $24.4 \%(n=138)$ traveled more than seven days, working long stretches of road - long route. As for the type of load, 37.7\% $(n=213)$ they carried wood; $21.8 \%(n=123)$ varied loads; $14.7 \%(n=83)$ bulk; $11.9 \%$ $(n=67)$ foods; $9.9 \%(n=56)$ live load; e $2.3 \%(n=13)$ fluids.

\section{Measures}

A self-applied instrument consisting of four blocks was used:

1. Sociodemographic (age, marital status, children, education) and work questionnaires (type of bond, presence of company on trips, number of days in travel/ work, number of days off, remuneration, worked hours / day, professional working time and load type).

2. Self-Reporting Questionnaire (SRQ-20), developed by Harding et al. (1980) and with evaluation of the validity evidence for Brazil by Mari and Willians (1986). In this case, it presented sensitivity of $86.33 \%$ and specificity of $89.31 \%$. The discriminating power for psychiatric diagnosis of SRQ-20 was 0.91. The instrument has 20 items, which evaluate two dimensions (physical symptoms - four items and psycho-emotional disorders - sixteen items). It consists of four symptom groups (Depressive/Anxious Mood, Somatic Symptoms, Decreased Vital Energy, Depressive Thoughts), which are assessed using a dichotomous scale (yes / no) for each of your questions. For each affirmative answer, the value of 1 is scored, resulting in its sum. The obtained scores indicate the probability of the presence of nonpsychotic disorders, which may vary from 0 (no probability) to 20 (extreme probability). The internal consistency obtained in the present study, assessed by the Kuder-Richardson coefficient (KR20), was 0.80 .

3. Subscales of the Psychosocial Stressors Scale in the Labor Context (Ferreira et al., 2015). Six subscales were used, totaling 31 items: 1 . Conflict and ambiguity of roles (five items, $\alpha=0.77$ ), referring to the lack of clarity regarding their own functions and the receiving of contradictory demands about the functions performed in this role, in this study $\alpha=0.67 ; 2$. Role overload (six items, $\alpha=0.71$ ), which consists on the excess of tasks requested to the employee, in this study $\alpha=0.65 ; 3$. Lack of social support (six items, $\alpha=0.77$ ), which refers to the difficulties arising from the lack of emotional support received by colleagues and superiors in their daily work, in this study, $\alpha=0.84 ; 4$. Lack of autonomy (five items, $\alpha=0.71$ ), which refers to the difficulties of planning and making decisions about their own tasks, work controls, in this study $\alpha=0.67 ; 5$. Work-family conflict (five items, $\alpha=0.75$ ), which perceives the relationship of incompatibility between family and work responsibilities, in this study $\alpha=0.61 ; 6$. Pressure of the degree of responsibility (four items, $\alpha=0.77$ ), about people and equipment that the employee has in the performance of his duties, in this study $\alpha=0.89$. These items were assessed using a five-point frequency scale (0 "never" to 4 "daily").

4. Occupational stressor questionnaire for truckers, designed specifically for this study based on the literature on stressors of these professionals (Cavagioni et al., 2009; Delfino \& Moraes, 2015; Silva, Luz, Vasconcelos, Marqueze, \& Moreno, 2016; Ulhôa et al (2010; Van der Beek, 2012). This has 14 items that evaluated the Infrastructure of the highways and the stops (road conditions, service stations, restroom conditions, place to eat), Insecurity (robberies and assault), Traffic (traffic jam, accidents) , Pollution (noise, environmental), Workday, Remuneration, Electronic control systems, and Operational support teams. The items were evaluated by a four-point scale (1 "not stressful" to 4 "very stressful"). The internal consistency, assessed by the Kuder-Richardson coefficient (KR20), was 0.77 .

\section{Data Collection Procedures}

Initially, contact was made with the locations to expose the research objective and establish the logistic of data collection, from March to June 2017. A pilot instrument study was carried out in February 2017, with 12 truck drivers not belonging to the study sample, which resulted in the suggestion of an occupational stressor - operational support teams, to be included in the instrument.

The application was performed collectively and in person by the researcher and five previously trained psychologists, in six transportation companies, three Driver Training Centers (DTCs), two gas stations and 15 Dangerous and Indivisible Goods Handling Course classes for these professionals.

The collection was performed after reading and signing the Informed Consent Form, and the instruments were filled in at their own places and collected after finalization. Filling time average was 50 minutes. The study has approval of the Research Ethics Committee of the Universidade do Vale 
do Rio dos Sinos (UNISINOS) under the CAAE protocol: 62418116.7.0000.5344.

\section{Data Analysis Procedures}

Initially, descriptive statistics of the study variables were performed in terms of their absolute and relative distribution. Continuous quantitative variables were categorized based on their quartiles with cutoff points at $\mathrm{Q}_{1},>\mathrm{Q}_{2}$ to $\mathrm{Q}_{3}$, and greater than $\mathrm{Q}_{3}$.

The answers possibilities of the instruments were transformed into dichotomous categorical variables. The subscales of the Psychosocial Stressors in the Labor Context scale were categorized by the median (2.50), and below this value was considered absence of risk and scores above the value as presence of risk. For occupational stressors, answers 1 and 2 were categorized as non-stressful assessment and response possibilities 3 and 4 considered stressful.

For the bivariate analysis between categorical variables, Pearson's chi-square test $\left(\chi^{2}\right)$, Fisher's exact test (Monte Carlo simulation) were used, with the purpose of initial exploration of crude associations. Comparative analyzes were complemented with estimated effect measure, the raw odds ratio (OR), with a $95 \%$ confidence interval $(95 \% \mathrm{CI})$.

Due to the high number of predictor factors and considering the sample size for one of the dependent responses (With CMD $=37$ ), the independent variables were analyzed by allocated blocks as follows: Block 1 - Sociodemographic Data; Block 2 - Working; Block 3 Occupational Stressors; and Block 4 - Psychosocial Risks.
The outcome variable was CMD, as measured by the SQR-20, and truck drivers who answered seven or more questions positively, based on the study by Santos, Araújo, Pinho and Silva (2010), were considered suspicious of CMD. Thus, all those who had this number of positive responses made up the group with CMD.

The Multivariate Binary Logistic Regression technique was implemented. The variables selected for multivariate analysis were all independent variables with values of $p \leq$ 0.200 in the bivariate analysis, in order to avoid excluding potentially important variables (Hosmer \& Lemeshow, 2000).

For the selection of representative variables, the conditional Backward selection method was used from the saturated model. To detect the adequacy/quality of the generated models, the tests known as Pseudo $\mathrm{R}^{2}-\mathrm{Cox}$, Snell and Nagelkerk were considered - which indicate the power of explanation of the independent variables over the dependent variable. The association of regression between independent variables and outcome was analyzed with the maximum likelihood ratio test (likelihood-ratiotest $2 \mathrm{LL}$ or $-2 \log )$.

The probability of gradual entry of the variables in the model was 0.05 and for the removal, 0.10 . Regarding the cutoff point, the significance was 0.50 for a maximum of 20 interactions. Significance levels below 0.01 were considered significant based on the Bonferroni criterion. Data were analyzed in the Statistical Package for Social Sciences program version 22 (PASW, Inc., Chicago, IL) for Windows, being that for statistical decision criterion, the significance level of $\mathrm{p}<0.05$ was adopted.

\section{RESULTS}

The prevalence of CMD found was $6.5 \%$. The results presented in Table 1 show that, among the sociodemographic variables, none of them had a statistically significant association with CMD at this stage of the analysis.

The results in Table 2 indicate associations with working characteristics. It was verified that the variables, work route, remuneration, daily workload and type of cargo transported were associated with CMD.

As for occupational stressors (Table 3), all were associated with CMD. Working hours (9.98) and road conditions (9.68) were the most significant stressors regarding the odds ratios for CMD.

Table 4 indicates the associations of CMD with Psychosocial Risks in the work context. The dimensions conflict and ambiguity of roles, role overload, lack of autonomy, work-family conflict and pressure of the degree of responsibility presented statistically significant associations.

Table 5 presents the predictors of the CMD group for each of the blocks listed in this study, except for the block of sociodemographic variables, since in the bivariate analysis, none of the variable reached the minimum significance level, that is, greater than 0.200 .

In the block of working variables, the initial model was composed by the factors Route, Remuneration, Daily Journey and Type of load. The final model was defined in five stages, which classified correctly $50.0 \%$ of the group with CMD; and $55.3 \%$ of the group without CMD, which implies an average proportion of $52.6 \%$ of correct answers. According to Nagelkerke statistics, it is estimated that the final model was able to explain $17.3 \%$ of the variations recorded in the group with CMD.

Regarding the block of variables related to occupational stressors, the initial model was composed of all items of the instrument. The final model, listed as the most reliable to answer those with CMD, in 10 steps, correctly classified $68.6 \%$ of the cases analyzed. In the group with CMD, the proportion of correct answers was $56.7 \%$. According to the results of Table 4, the stressors Accidents, Road conditions, 
Table 1

Description of sociodemographic data according to CMD classification

\begin{tabular}{|c|c|c|c|c|c|c|}
\hline \multirow{3}{*}{ Variables } & \multicolumn{5}{|c|}{ CMD Classification } & \multirow{3}{*}{$\begin{array}{c}\text { Odds Ratio Unajusted } \\
\text { OR (IC95\%) }\end{array}$} \\
\hline & \multicolumn{2}{|c|}{ without $\mathrm{CMD}(\mathrm{n}=528)$} & \multicolumn{2}{|c|}{ with CMD $(n=37)$} & \multirow{2}{*}{$p$} & \\
\hline & $\mathbf{n}$ & $\%$ & $\mathbf{n}$ & $\%$ & & \\
\hline Age range & & & & & $0,388 \S$ & \\
\hline Up to 31 years & 140 & 27.4 & 14 & 37.8 & & $1.09(0.96-1.28)$ \\
\hline Over 31 to 45 & 249 & 48.7 & 15 & 40.5 & & $0.77(0.52-1.08)$ \\
\hline Over 45 years & 122 & 23,9 & 8 & 21.6 & & 1.0 \\
\hline Schooling & & & & & $0.781 £$ & \\
\hline Elementary School & 232 & 44.7 & 17 & 45.9 & & 1.0 \\
\hline High school & 280 & 53.9 & 19 & 51.4 & & $0.98(0.67-1.17)$ \\
\hline University education & 7 & 1.3 & 1 & 2.7 & & $1.47(0.88-1.89)$ \\
\hline Marital status & & & & & $0.638 \S$ & \\
\hline With Partner & 456 & 86.5 & 31 & 83.8 & & 1.0 \\
\hline No partner & 71 & 13.5 & 6 & 16.2 & & $1.24(0.50-3.11)$ \\
\hline Children & & & & & $0.515 \S$ & \\
\hline Yes & 409 & 77.6 & 27 & 73.0 & & 1.0 \\
\hline No & 118 & 22.4 & 10 & 27.0 & & $1.28(0.60-2.72)$ \\
\hline
\end{tabular}

$\S$ Pearson's chi-square test;

$£$ Fisher's exact test

Food places, as well as the Workday and Remuneration factors remained as representative in the final model. The set of factors that formed the final model accounted for $31.1 \%$ (Nagelkerk) of the variations observed in the CMD group.

Regarding the block of variables Psychosocial Risks, the dimensions of conflict and ambiguity of roles, overload of roles, lack of autonomy, work/family conflict and pressure of degree of the responsibility were included in the initial model. In the final model, selected in 3 steps, there was a higher proportion of correct classification, $70.8 \%$ of cases without CMD and with CMD.

The dimensions of greatest impact to explain CMD were the presence of work/family conflict and the pressure of degree of the responsibility. The explanatory power on CMD variations was estimated at $32.8 \%$ (Nagelkerk).

Table 6 presents the general Multivariate Binary Logistic Regression model, which simultaneously analyzed all the potential predictors. It is observed that the capacity to explain the variations in the CMD was $39.9 \%$ (Nagelkerk
R2), while the proportion of correctly classified cases for the total model reached $79.8 \%$, being $86.2 \%(n=351)$ in the group without CMD and $73.3 \%(\mathrm{n}=22)$ in the group with CMD. The variables associated with CMD were: daily journey over 12 hours; miscellaneous transported cargo; the conditions of the roads, eating places and working hours stressors; and psychosocial risks, work/family conflict, and pressure of degree of the responsibility. Regarding the factors with the greatest impact to explain CMD, the results showed that the presence of working hours stressor implied an increase of 5.41 times more chance of truck driver presenting CMD; the conditions of the roads stressors, 4.53 times more; and the presence of psychosocial risk of work/family conflict, 3.43 times more chance of CMD. The remaining variables in the model, although not presenting a minimum level of representative significance, are important because they influence the explanatory power of the effectively significant variables, according to Cox, Snell and Nagelkerk indicators.

\section{DISCUSSION}

The present study aimed to identify sociodemographic, workings, psychosocial risks and occupational stressors factors associated with CMD in truck drivers. The results indicated that the working variables hours over 12 hours daily, type of varied load, conditions of the roads, places to eat and working hours stressors, as well as the psychosocial risks work-family conflict and pressure of the degree of responsibility constitute factors associated with CMD.

The element associated with psychic illness with the highest chance of being affected was the occupational 
Table 2

Description of Working data according to CMD classification

\begin{tabular}{|c|c|c|c|c|c|c|}
\hline \multirow{3}{*}{ Variables } & \multicolumn{5}{|c|}{ CMD Classification } & \multirow{3}{*}{$\begin{array}{c}\text { Odds Ratio Unajusted } \\
\text { OR (IC95\%) } \\
\end{array}$} \\
\hline & \multicolumn{2}{|c|}{ without CMD $(n=528)$} & \multicolumn{2}{|c|}{ with CMD (n=37) } & \multirow{2}{*}{$p$} & \\
\hline & $\mathbf{n}$ & $\%$ & $\mathbf{n}$ & $\%$ & & \\
\hline Bond Type & & & & & $>0.999 £$ & \\
\hline Employee & 452 & 86.3 & 33 & 89.2 & & $1.12(0.45-1.56)$ \\
\hline Aggregate & 9 & 1.7 & 0 & 0.0 & & $-\ldots$ \\
\hline Outsourced & 15 & 2.9 & 1 & 2.7 & & $0.88(0.54-1.09)$ \\
\hline Self-employed & 48 & 9.2 & 3 & 8.1 & & 1.0 \\
\hline Travel Status & & & & & $0.126 £$ & \\
\hline With companion & 55 & 10.5 & 1 & 2.7 & & 1.0 \\
\hline No companion & 468 & 89.5 & 36 & 97.3 & & $1.05(1.01-1.11)$ \\
\hline Work route & & & & & $<0.001 \S$ & \\
\hline Short & 293 & 59.7 & 13 & 35.1 & & 1.0 \\
\hline Average & 80 & 16.3 & 4 & 10.8 & & $0.89(0.34-1.11)$ \\
\hline Long & 118 & 24.0 & 20 & 54.1 & & $2.58(1.10-4.39)$ \\
\hline Remuneration & & & & & $0.019 \S$ & \\
\hline Up to 2000 & 163 & 34.5 & 4 & 11.4 & & 1.0 \\
\hline Above 2000 and 3300 & 196 & 41.4 & 19 & 54.3 & & $1.29(1.08-4.55)$ \\
\hline Above 3300 & 114 & 24.1 & 12 & 34.3 & & $2.88(1.76-7.66)$ \\
\hline Daily journey & & & & & $<0.001 \S$ & \\
\hline Up to 12 & 417 & 83.1 & 18 & 50.0 & & 1.0 \\
\hline Above 12 & 85 & 16.9 & 18 & 50.0 & & $4,91(2,45-9,82)$ \\
\hline Professional working time & & & & & $0.708 \S$ & \\
\hline Up to 4 years & 107 & 20.6 & 6 & 16.2 & & 1.0 \\
\hline Above 4 and 18 anos & 285 & 54.8 & 20 & 54.1 & & $0.91(0.74-1.06)$ \\
\hline Above 18 & 128 & 24.6 & 11 & 29.7 & & $1.15(0.84-1.66)$ \\
\hline Load Type & & & & & $0.003 £$ & \\
\hline Foods & 63 & 12.1 & 4 & 11.4 & & 1.00 \\
\hline Live load & 55 & 10.6 & 1 & 2.9 & & -- \\
\hline Fluids & 13 & 2.5 & 0 & 0.0 & & -- \\
\hline Bulk & 81 & 15.6 & 2 & 5.7 & & -- \\
\hline Wood & 202 & 38.8 & 11 & 31.4 & & $0.86(0.76-0.94)$ \\
\hline Varied loads & 106 & 20.4 & 17 & 48.6 & & $3.27(1.19-6.78)$ \\
\hline
\end{tabular}

$\S$ Pearson's chi-square test;

$£$ Fisher's exact test

stressor workday. This result confirms a study by Ulhôa et al. (2010), being the highest risk variable, indicating a 2.68 increased chance of presenting CMD.

The daily working day of the truck driver authorized by law 13.103 is up to 12 working hours. This workload can cause increased fatigue and accident risk, there is also an exponential increase in accident risk from 12 hours on (Narciso \& Mello, 2017). In the present study, professionals who work more than 12 hours have a 3.33 times greater chance of having CMD; and among those who consider the workday a stressor, the chance is 5.41. In summary, excessive working hours, often marked by long hours, pressure for delivery, repetitive tasks, uninterrupted driving hours, irregular working hours and insufficient rest have been associated with a number of mental health problems (Apostolopoulos et al., 2010).

These results are important and illuminating as long-time professionals are exposed to many risk factors such as sleep, 
Table 3

Absolute and relative distribution of occupational stressors according to CMD classification

\begin{tabular}{|c|c|c|c|c|c|c|}
\hline \multirow{3}{*}{ Variables } & \multicolumn{5}{|c|}{ Classification CMD } & \multirow{3}{*}{$\begin{array}{c}\begin{array}{c}\text { Odds Ratio } \\
\text { Unajusted }\end{array} \\
\text { OR (IC95\%) }\end{array}$} \\
\hline & \multicolumn{2}{|c|}{ without CMD $(n=528)$} & \multicolumn{2}{|c|}{ with CMD (n=37) } & \multirow{2}{*}{$p$} & \\
\hline & $\mathbf{n}$ & $\%$ & $\mathbf{n}$ & $\%$ & & \\
\hline Road conditions & & & & & $<0.001 £$ & \\
\hline No & 240 & 46.1 & 3 & 8.1 & & 1.00 \\
\hline Yes & 281 & 53.9 & 34 & 91.9 & & $9.68(2.93-31.9)$ \\
\hline Service stations & & & & & $<0.001 \S$ & \\
\hline No & 431 & 82.9 & 20 & 54.1 & & 1.00 \\
\hline Yes & 89 & 17.1 & 17 & 45.9 & & $4.11(2.07-8.17)$ \\
\hline Restroom conditions & & & & & $<0.001 \S$ & \\
\hline No & 436 & 83.5 & 21 & 56.8 & & 1.00 \\
\hline Yes & 86 & 16.5 & 16 & 43.2 & & $3.86(1.93-7.70)$ \\
\hline Place to eat & & & & & $<0.001 \S$ & \\
\hline No & 477 & 92.1 & 26 & 70.3 & & 1.00 \\
\hline Yes & 41 & 7.9 & 11 & 29.7 & & $4.92(2.27-10.67)$ \\
\hline Assault & & & & & $0.142 \S$ & \\
\hline No & 174 & 33.3 & 8 & 21.6 & & 1.00 \\
\hline Yes & 348 & 66.7 & 29 & 78.4 & & $1.81(0.81-4.05)$ \\
\hline Robberies & & & & & $0.116 \S$ & \\
\hline No & 165 & 32.0 & 7 & 19.4 & & 1.00 \\
\hline Yes & 351 & 68.0 & 29 & 80.6 & & $1.94(0.84-4.54)$ \\
\hline Traffic jam & & & & & $0.001 \S$ & \\
\hline No & 225 & 43.0 & 5 & 13.9 & & 1.00 \\
\hline Yes & 298 & 57.0 & 31 & 86.1 & & $4.68(1.79-12.23)$ \\
\hline Accidents & & & & & $0.007 \S$ & \\
\hline No & 182 & 35.1 & 5 & 13.5 & & 1.00 \\
\hline Yes & 337 & 64.9 & 32 & 86.5 & & $3.45(1.32-9.02)$ \\
\hline Pollution noise & & & & & $0.005 \S$ & \\
\hline No & 266 & 51.2 & 10 & 27.0 & & 1.00 \\
\hline Yes & 254 & 48.8 & 27 & 73.0 & & $2.83(1.34-5.96)$ \\
\hline Pollution environmental & & & & $0.192 \S$ & & \\
\hline No & 194 & 37.7 & 10 & 27.0 & & 1.00 \\
\hline Yes & 320 & 62.3 & 27 & 73.0 & & $1.63(0.77-3.45)$ \\
\hline Workday & & & & & $<0.001 \S$ & \\
\hline No & 438 & 84.4 & 13 & 35.1 & & 1.00 \\
\hline Yes & 81 & 15.6 & 24 & 64.9 & & $9.98(4.88-20.41)$ \\
\hline Remuneration & & & & & $<0.001 \S$ & \\
\hline No & 393 & 76.6 & 13 & 35.1 & & 1.00 \\
\hline Yes & 120 & 23.4 & 24 & 64.9 & & $6.05(2.99-12.24)$ \\
\hline Electronic control systems & & & & & $<0.001 \S$ & \\
\hline No & 389 & 75.5 & 15 & 42.9 & & 1.00 \\
\hline Yes & 126 & 24.5 & 20 & 57.1 & & $4.12(2.05-8.28)$ \\
\hline Operational support teams & & & & & $<0.001 \S$ & \\
\hline No & 436 & 84.2 & 21 & 58.3 & & 1.00 \\
\hline Yes & 82 & 15.8 & 15 & 41.7 & & $3.80(1.88-7.67)$ \\
\hline
\end{tabular}

$\S$ Pearson's chi-square test;

$£$ Fisher's exact test 
Dimensions of Psychosocial Risks in the Work Context according to the CMD classification

\begin{tabular}{|c|c|c|c|c|c|c|}
\hline \multirow{3}{*}{ Variables } & \multicolumn{5}{|c|}{ Classification CMD } & \multirow{3}{*}{$\begin{array}{c}\begin{array}{c}\text { Odds Ratio } \\
\text { Unajusted }\end{array} \\
\text { OR (IC95\%) }\end{array}$} \\
\hline & \multicolumn{2}{|c|}{ without $\mathrm{CMD}(\mathrm{n}=528)$} & \multicolumn{2}{|c|}{ with CMD (n=37) } & \multirow{2}{*}{$p$} & \\
\hline & $\mathbf{n}$ & $\%$ & n & $\%$ & & \\
\hline Conflict and ambiguity of roles & & & & & $0.045 £$ & $3.45(1.38-14.27)$ \\
\hline No & 514 & 97.3 & 33 & 89.2 & & \\
\hline Yes & 14 & 2.7 & 4 & 10.8 & & \\
\hline Role overload & & & & & $0.108 \S$ & $1.73(0.88-3.42)$ \\
\hline No & 286 & 54.2 & 15 & 40.5 & & \\
\hline Yes & 242 & 45.8 & 22 & 59.5 & & \\
\hline Lack of social support & & & & & $0.214 \S$ & $1.52(0.78-2.97)$ \\
\hline No & 326 & 61.7 & 19 & 51.4 & & \\
\hline Yes & 202 & 38.3 & 18 & 48.6 & & \\
\hline Lack of autonomy & & & & & $0.022 \S$ & $2.15(1.10-4.21)$ \\
\hline No & 367 & 69.5 & 19 & 51.4 & & \\
\hline Yes & 161 & 30,5 & 18 & 48.6 & & \\
\hline Work-family conflict & & & & & $<0.001 \S$ & $6.33(2.59-15.44)$ \\
\hline No & 506 & 95.8 & 29 & 78.4 & & \\
\hline Yes & 22 & 4.2 & 8 & 21.6 & & \\
\hline Pressure of the degree of responsibility & & $0.007 \S$ & $2.47(1.25-4.88)$ & & & \\
\hline No & 332 & 62.9 & 15 & 40.5 & & \\
\hline Yes & 196 & 37.1 & 22 & 59.5 & & \\
\hline
\end{tabular}

$\S$ Pearson's chi-square test;

$£$ Fisher's exact test

stress, unhealthy habits, illness and medical complications. Consequently, they are exposed to adverse driving events, increasing the risk of collision (Crizzle et al., 2017). Some authors point out that the work environment exposes truck drivers to long working hours, long shifts, noise and environmental pollution, and a non-health-enhancing lifestyle (Bigelow et al., 2014; Lemke et al., 2015; Van der Beek, 2012), making these workers more vulnerable with high levels of occupational stress, which increases the risk of psychological disorders (Apostolopoulos et al., 2013).

The association of CMDs with the type of cargo carried can be explained by requiring constant professional adaptation, due to the care, transport and loading and unloading being different in with each trip (Van der Beek, 2012). And also from the perspective of multiple tasks, the variability of loads influences driving modes and their effects, especially in relation to the time required for cargo delivery (Delfino \& Morais, 2015).

Road conditions, another stressor associated with CMD, affect driver and vehicle safety, leaving the professional more exposed to accidents, vehicle breakdown, increased fuel consumption, among other important variables in safe and economical driving (Silva et al. al., 2016; Ulhôa et al., 2010). Road conditions have been considered a stressor rooted in the transportation environment (Shattell et al., 2012; Shattell et al., 2010). The bad conditions of Brazilian routs and highways are portrayed in the study by NTC (2016), which points out that $58.2 \%$ of the road network presents some kind of problem, which increases the operational cost of road transport, increases the likelihood of accidents, it decreases the performance of vehicles and the quality of service, as well as it harms the environment.

The local stressor for food refers to the fact that the organization of the work does not favor the truck driver in order to have their meals properly, due to the lack of appropriate places and, when they exist, they are in the custody of gas stations (Delfino \& Morais, 2015), because vehicle supply is linked to the opportunity of taking advantage of the infrastructure available at these locations. The places used for food are usually the truck kitchen (box) or roadside restaurants (Cavagioni et al., 2009; Paris et al., 2013)

Most of the time, the food supply is of high caloric value and low nutritional value (Cavagioni et al., 2009), with direct impacts on workers' health, making them vulnerable to hypertension, overweight, among other diseases (Alessi \& Alves, 2015; Shattell et al., 2012). The association of local food stressors with CMD involvement is a recent result in 
Table 5

Multivariate binary logistic regression models to explain CMDs

\begin{tabular}{|c|c|c|c|c|c|c|}
\hline \multirow{3}{*}{ Variables independent } & \multicolumn{3}{|c|}{ Regression coefficient } & \multicolumn{3}{|c|}{ Odds Ratio Ajusted } \\
\hline & \multirow{2}{*}{$\mathbf{B}$} & \multirow{2}{*}{ S.E. } & \multirow{2}{*}{ Sig. } & \multirow{2}{*}{$\mathbf{O R}_{\mathrm{aj}}$} & \multicolumn{2}{|c|}{ IC95\% } \\
\hline & & & & & \multicolumn{2}{|c|}{ Confidence Interval } \\
\hline \multicolumn{7}{|l|}{ Remuneration } \\
\hline Abouve 3300 & 0.318 & 0.457 & 0.036 & 1.67 & 1.16 & 4.36 \\
\hline \multicolumn{7}{|l|}{ Daily journey } \\
\hline Abouve $12 \mathrm{~h}$ & 1.987 & 0.552 & $<0.001$ & 7.29 & 2.47 & 21.50 \\
\hline \multicolumn{7}{|l|}{ Load Type } \\
\hline Varieds Loads & 0.789 & 0.645 & 0.021 & 2.20 & 1.62 & 7.78 \\
\hline \multicolumn{7}{|l|}{ Occupational stressors B } \\
\hline Road conditions & 1.173 & 0.654 & 0.073 & 3.23 & 0.90 & 11.65 \\
\hline Place to eat & 0.938 & 0.477 & 0.049 & 2.56 & 1.00 & 6.51 \\
\hline Accidents & 0.891 & 0.576 & 0.122 & 2.44 & 0.79 & 7.54 \\
\hline Workday & 1.669 & 0.426 & 0.000 & 5.31 & 2.30 & 12.22 \\
\hline Remuneration & 0.947 & 0.436 & 0.030 & 2.58 & 1.10 & 6.06 \\
\hline \multicolumn{7}{|l|}{ Psychosocial Risks C } \\
\hline Conflict and ambiguity of roles & 1.182 & 0.651 & 0.070 & 3.26 & 0.91 & 11.68 \\
\hline Lack of autonomy & 0.637 & 0.358 & 0.075 & 1.89 & 0.94 & 3.81 \\
\hline Work-family conflict & 1.456 & 0.481 & 0.002 & 4.29 & 1.67 & 11.02 \\
\hline Pressure of the degree of responsibility & 0.776 & 0.360 & 0.031 & 2.17 & 1.07 & 4.40 \\
\hline
\end{tabular}

Model A - Note: R2 de Nalgelkerke 0,173; Proof by Hosmer-Lemeshow (Pearson's chi-square = 1.466; p=0.983); Cox \& Snell: 0.068; Odds ratio confusion matrix: $52.6 \%$ [without CMD: $55.3 \%(\mathrm{n}=225) /$ with CMD: $50.0 \%(\mathrm{n}=15)$ ];

Model B - Note: R2 de Nalgelkerke 0.311; Proof by Hosmer-Lemeshow (Pearson's chi-square = 3.469; p=0.839); Cox \& Snell: 0.124; Odds ratio confusion matrix: 68.6\% [without CMD: $80.5 \%(\mathrm{n}=328)$ / with CMD: $56.7 \%(\mathrm{n}=17)$ ];

Model C - Note: R2 de Nalgelkerke 0.328; Proof by Hosmer-Lemeshow (Pearson's chi-square = 3.549; p=0.314); Cox \& Snell: 0.142; Odds ratio confusion matrix: $70.8 \%$ [without CMD: $81.5 \%(\mathrm{n}=332)$ / with CMD: $60.0 \%(\mathrm{n}=18)$ ];

Table 6

Explanatory General Model for CMD

\begin{tabular}{|c|c|c|c|c|c|c|}
\hline \multirow{3}{*}{ Variables independent } & \multicolumn{3}{|c|}{ Regression coefficient } & \multicolumn{3}{|c|}{ Odds Ratio Ajusted } \\
\hline & \multirow{2}{*}{ B } & \multirow{2}{*}{ S.E. } & \multirow{2}{*}{ Sig. } & \multirow{2}{*}{$\mathrm{OR}_{\mathrm{aj}}$} & \multicolumn{2}{|c|}{ IC95\% } \\
\hline & & & & & \multicolumn{2}{|c|}{ Confidence Interval } \\
\hline \multicolumn{7}{|l|}{ Daily journey } \\
\hline Abouve $12 \mathrm{~h}$ & 1.202 & 0.564 & 0.033 & 3.33 & 1.10 & 10.04 \\
\hline \multicolumn{7}{|l|}{ Load Type } \\
\hline Varieds & 0.990 & 0.725 & 0.172 & 2.69 & 0.65 & 11.14 \\
\hline Road conditions & 1.512 & 0.671 & 0.024 & 4.53 & 1.22 & 16.88 \\
\hline Place to eat & 1.003 & 0.495 & 0.043 & 2.73 & 1.03 & 7.19 \\
\hline Workday & 1.689 & 0.441 & 0.000 & 5.41 & 2.28 & 12.85 \\
\hline Work-family conflict & 1.234 & 0.598 & 0.039 & 3.43 & 1.06 & 11.09 \\
\hline Pressure of the degree of responsibility & 0.810 & 0.452 & 0.074 & 2.25 & 0.93 & 5.45 \\
\hline
\end{tabular}

Model General - Note: $\mathrm{R}^{2}$ in Nalgelkerke 0.399; Proof by Hosmer-Lemeshow (Pearson's chi-square = 3.918; p=0,789); Cox \& Snell: 0.163; Odds ratio - confusion matrix: $79.8 \%$ [without CMD: $86.2 \%(\mathrm{n}=351)$ / with CMD: $73.3 \%(\mathrm{n}=22)$ ]; 
the literature, probably due to the need for stops and breaks, as a result of truck driver law enforcement.

Regarding psychosocial risks in the work context, the dimensions, pressure of the degree of responsibility and work/family conflict were associated with CMD. The first dimension is understood as the responsibility of the worker with people and equipment; and the second refers to the incompatibility of work and family sphere responsibilities (Ferreira et al., 2015).

The pressure on the degree of responsibilities can be explained by changes in the work organization of these professionals and the high demand for responsibilities to which they are subject (Van der Beek, 2012). With the advent of technology, trucks are equipped with trackers and controllers, which puts pressure on the professional, who has the duty to report all their actions to a central, which regulates and monitors them for 24 hours.

Time pressure (Shattell et al., 2012; Shattell et al., 2010), traffic, road safety and responsibility for other drivers (Apostolopoulos et al., 2016) are stressors present in the routine of road transport. The demand for the ofteninsufficient delivery time exposes these professionals (Shattell et al., 2010) to a context that generates psychosocial risks (Van der Beek, 2012). Another demand refers to commercial interaction with customers, as it is considered the communication channel, reporting difficulties and seeking solutions to problems.

The work-family conflict refers to the organization of the work of these professionals, which promotes a distance from the family. The truck driver tends not to participate in family events and daily interactions, vital to family bonding, due to their livelihoods and ongoing work demands (Apostolopoulos et al., 2016; Shattell et al., 2010).

The isolation resulting from lack of contact with friends and family, the absence of family routine for long periods, loneliness, anxiety and depression are factors that the truck driver faces daily in the exercise of his profession (Apostolopoulos et al., 2016; Bigelow et al., 2014; Lemke et al., 2015; Van der Beek, 2012), causing greater risk of mental distress to these workers (Fan et al., 2012). Truck drivers assign a variety of roles to their spouses, such as child educacion, home economics and home responsibilities, which causes family stress because they are far from regular living (Apostolopoulos et al., 2016; Shattell et al (2012; Shattell et al., 2010).

Finally, the truck driver is subject to stressors considered endemic to the transportation sector, such as long working hours, driving conditions caused by traffic and the environment, a combination of kilometer-based pay, pressure for deliveries, often facing physical hazards, safety, traffic accidents and lack of health care support networks, as well as discrimination in the profession, loneliness, anxiety and depression (Apostolopoulos et al., 2016, Shattell et al., 2012; Shattell et al., 2010) . According to the authors, occupational stressors have been reflected in the reduced life expectancy of truck drivers and caused a series of comorbidities.

\section{CONCLUSION}

The study results reveal a risk profile consisting of occupational, psychosocial and occupational stressors variables, confirming that environmental and contextual factors are important for the development of CMD, according to Goldberg and Huxley (1992). These results point to the need for greater attention to occupational health in this professional category, unattended in this area due to the organization of their work (Apostolopoulos et al., 2016, Shattell et al., 2012; Shattell et al., 2010). In this sense, it is suggested mental health support networks in strategic locations as a reasonable measure and traceability, since the difficulty of access to health on the roads causes a neglect with the health of these workers (Cavagioni et al., 2009; Shattell et al., 2012).

Changes in Law 13.103/2015 regarding working hours of these workers is required. The workload approved by law (12h) does not guarantee the safety conditions of these workers (Narciso \& Mello, 2017), and in the present study, the working day was the most relevant predictor of the CMD. Inspection and intervention in the transport sector in relation to working hours is a way to preserve the occupational health of this worker.
The improvement of the conditions of the Brazilian roads is part of the Planejamento Nacional de Logística e Transportes (National Logistics and Transport Planning), thus, it is the competent government agencies to ensure its implementation, in order to improve the working conditions of these professionals, avoiding the wear and break of the vehicle, accidents, travel difficulties and traffic jams. About the places for food, it is suggested to use the project of the Ministry of Transport (Portaria $n^{\circ} .944$ ), about stopping and resting points as possibilities for an appropriate place for the food of these workers. Information on healthy eating practices at truck stops is also recommended.

The implementation of actions at the organizational level is necessary. Companies and managers are responsible for the development of occupational health promotion and prevention programs through training, lectures and educational campaigns. Also a look about the deadlines in the opportunity of closing contracts, is essential to ensure proper working conditions of these workers.

Actions focused on the logistics of the routes, providing the worker a better relationship with the family, help to balance the work and family spheres. Another action 
would be the availability of Wi-Fi to access social media, connecting the truck driver to the company, family and friends in order to establish social support networks. By organizing the work of the road sector, in which social isolation is a constant, the use of the social medias would have a positive impact in reducing the distancing and monitoring of family and social experiences.

It is important to highlight two strengths of the study, such as the predictive power of the variables that constituted the explanatory model of CMD, which is considered high (39.9\%) (Hair et al., 2009), and the proportion of correctly classified cases $(79.8 \%)$. Regarding the limitations, the research presents some that should be considered for reading its results. The first concerns its cross-sectional design, which makes it impossible to establish causal relations. The second is due to the non-random sample type that does not allow the generalization of their results. The third, because part of the collection was carried out in respondents' workplaces and in license renewal sites, which may generate response visions to the extent that the worker may have been somewhat afraid to answer items that may compromise remain in employment or have their qualifications renewed. A fourth limitation may be the effect of the healthy worker (self-selection bias) that often excludes the potential sick because healthier workers are more likely to stay in the workforce than those who are sick (McMichael, 1976).
In this sense, it is suggested to perform longitudinal studies of mixed methods from multiple sources, allowing to broaden the understanding of behavioral patterns and to elaborate explanatory and predictive models of variables in the field of Occupational Health Psychology (Abad \& Carlotto, 2016). From this perspective, it would broaden the knowledge about how the process of occupational stress develops over time and its relationship with the symptoms that characterize CMD and the predictive power of the variables that made up the model.

It would also contribute to the confirmation of the study model with stratified probabilistic samples in transport companies of different modalities. Such a strategy would allow access to a delimited population and construction of sample calculation including truck drivers on leave from work to estimate the prevalence of CMD and risk factors, reducing the effect of the healthy worker and allowing the generalization of results.

This study contributed to broaden the knowledge of the risk factors to which these professionals are subjected, making it possible to think about prevention and mental health promotion actions. These could ensure better psychic conditions of these professionals and prevent long-term illness leave, since CMDs are predictors of other occupational injuries as well to prevent leave due to professional abandonment.

\section{REFERENCES}

Abbad, G. S., \& Carlotto, M. S. (2016). Analyzing challenges associated with the adoption of longitudinal studies in Work and Organizational Psychology. Revista Psicologia: Organizações e Trabalho, 16(4), 340-348. https://doi.org/10.17652/ $\operatorname{rpot} / 2016.4 .12585$

Alessi, A., \& Alves, M. K. (2016). Hábitos de vida e condições de saúde dos caminhoneiros do Brasil: Uma revisão da literatura. Ciência \& Saúde, 8(3), 129-136. https://doi. org/10.15448/1983-652x.2015.3.18184

Apostolopoulos, Y., Sönmez, S., Hege, A., \& Lemke, M. (2016). Work strain, social isolation and mental health of long-haul truckers. Occupational. Therapy in Mental Health, 32(1), 5069. https://doi.org/10.1080/0164212X.2015.1093995

Apostolopoulos, Y., Sönmez, S., Shattell, M. M., \& Belzer, M. (2010). Worksite-induced morbidities among truck drivers in the United States. AAOHN Journal, 58(7), 285-296. https:// doi.org/10.3928/08910162-20100625-01

Apostolopoulos, Y., Sönmez, S., Shattell, M. M., Gonzales, C., \& Fehrenbacher, C. (2013). Health survey of US long-haul truck drivers: Work environment, physical health, and healthcare access. Work, 46(1), 113-123. https://doi.org/10.3233/WOR121553

Bigelow, P. L., Betts, D., Hogg-Johnson, S., Anick, B.C., Sieber, W. K., Skinner, M., \& Jakubicek, P. (2012). Health, safety, and wellness of truck drivers in Canada. In freight demand modeling: Tools for public-sector decision making, Summary of a conference (Vol. 40; pp. 95-105). Transportation Research Board.

Carlotto, M. S., Barcinski, M., \& Fonseca, R. (2015). Transtornos mentais comuns e associação com variáveis sociodemográficas e estressores ocupacionais: Uma análise de gênero. Estudos e Pesquisas em Psicologia, 15(3), 1006-1026. https://doi. org/10.12957/epp.2015.19424

Carlotto, M. S., \& Câmara, S. G. (2015). Prevalence and risk factors of common mental disorders among teachers. Revista de Psicología del Trabajo y de las Organizaciones, 31(3), 201206. https://doi.org/10.1016/j.rpto.2015.04.003

Cavagioni, L. C., Pierin, A. M. G., Batista, K. D. M., Bianchi, E. R. F., \& Costa, A. L. S. (2009). Health problems, hypertension and predisposition to stress in truck drivers. Revista da Escola de Enfermagem da USP, 43(SPE2), 1267-1271. https://doi. org/10.1590/S0080-62342009000600021

Confederação Nacional do Transporte. (2016) Boletim estatístico do Transporte. http://www.cnt.org.br/Boletim/boletimestatistico-cnt

Crizzle, A. M., Bigelow, P., Adams, D., Gooderham, S., Myers, A. M., \& Thiffault, P. (2017). Health and wellness of longhaul truck and bus drivers: A systematic literature review and directions for future research. Journal of Transport \& Health, 7(A), 90-109. https://doi.org/10.1016/j.jth.2017.05.359

Delfino, L. G., \& Moraes, T. D. (2015). Percepções sobre adoecimento para caminhoneiros afastados pelo sistema de previdência social. Estudos Interdisciplinares em Psicologia, 6(2), 113-137. https://doi.org/10.5433/22366407.2015v6n2p113

Fan, Z. J., Bonauto, D. K., Foley, M. P., Anderson, N. J., Yragui, N. L., \& Silverstein, B. A. (2012). Occupation and the prevalence of current depression and frequent mental distress, WABRFSS 2006 and 2008. American Journal of Industrial Medicine, 55(10), 893-903. https://doi.org/10.1002/ajim.22094

Ferreira, M. C., Milfont, T. L., Silva, A. P. C., Fernandes, H. A., Almeida, S. P., \& Mendonça, H. (2015). Escala para 
avaliação de estressores psicossociais no contexto laboral: Construção e evidências de validade. Psicologia: Reflexão e Crítica, 28(2), 340-349. https://doi.org/10.1590/16787153.201528214

Fonseca, R. M. C., \& Carlotto, M. S. (2011). Saúde mental e afastamento do trabalho em servidores do judiciário do Estado do Rio Grande do Sul. Psicologia em Pesquisa, 5(2), 117-125. http://pepsic.bvsalud.org/scielo.php?script=sci_arttext\&pid $=$ S1982-12472011000200004

Goldberg, D., \& Huxley, P. (1992). Common Mental Disorders. A bio-social model. Routledge. https://doi.org/10.1002/ smi.2460080416.

Hair, J. F., Black, W. C., Babin, B. J., \& Anderson, R. E., \& Tatham, R. L. (2009). Análise multivariada de dados. Bookman.

Hosmer, D.W., \& Lemeshow, S. (2000). Applied logistic regression. John Wiley \& Sons.

Krueger, G. P. (2013). Health and wellness for commercial truck, bus and motorcoach drivers: Wellness report. American Society of Safety Engineers.

Lemke, M., Hege, A., Perko, M., Sönmez, S., \& Apostolopoulos, Y., (2015). Work patterns, sleeping hours and excess weight in commercial drivers. Occupational Medicine 65(9), 725-731. https://doi.org/10.1093/occmed/kqv080

Ludermir, A. B., \& Melo Filho, D. A. D. (2002). Condições de vida e estrutura ocupacional associadas a transtornos mentais comuns. Revista de Saúde Pública, 36(2), 213-221. https://doi. org/10.1590/S0034-89102002000200014

Mari, J. J., \& Williams, P. (1986). A validity study of a psychiatric screening questionnaire (SRQ-20) in primary care in the city of Sao Paulo. The British Journal of Psychiatry, 148(1), 23-26. https://doi.org/10.1192/bjp.148.1.23

McMichael, A. J. (1976). Standardized mortality ratios and the healthy worker effect': Scratching beneath the surface. Journal of Occupational and Environmental Medicine, 18(3), 165-168. https://doi.org/10.1097/00043764-19760300000009

Mir, M. U., Khan, I., Ahmed, B., \& Razzak, J. A. (2012). Alcohol and marijuana use while driving an unexpected crash risk in Pakistani commercial drivers: A cross-sectional survey. BMC Public Health, 12(145), 1-7. https://doi.org/10.1186/14712458-12-145

Narciso, F. V., \& Mello, M. T. D. (2017). Safety and health of professional drivers who drive on Brazilian highways. Revista de Saúde Pública, 51(26), 1-7. https://doi.org/10.1590/s15188787.2017051006761

Nunes, M. A., Pinheiro, A. P., Bessel, M., Brunoni, A. R., Kemp, A. H., Benseñor, I. M., \& Schmidt, M. I. (2016). Common mental disorders and sociodemographic characteristics: Baseline findings of the Brazilian longitudinal study of adult health (ELSA-Brasil). Revista Brasileira de Psiquiatria, 38(2), 91-97. https://doi.org/10.1590/1516-4446-2015-1714

Paris, P., Grandi, G., Siviero, J., \& Pereira, F. B. (2013). Sono, estado nutricional e hábitos de vida de caminhoneiros. Ciência \& Saúde, 6(3), 197-205. https://doi.org/10.15448/1983652x.2013.3.13000

Reichenheim, M. E., Moraes, C. L., Lopes, C. S., \& Lobato, G. (2014). The role of intimate partner violence and other healthrelated social factors on postpartum common mental disorders: A survey-based structural equation modeling analysis. $B M C$
Public Health, 14(427), 1-14. https://doi.org/10.1186/14712458-14-427

Rodriguez-Lopez, M., Arrivillaga, M., Holguín, J., León, H., Ávila, A., Hernández, C., \& Rincón-Hoyos, H. G. (2016). Perfil del paciente hiperfrecuentador y su asociación con el trastorno ansioso depresivo en servicios de atención primaria de Cali, Colombia. Revista Peruana de Medicina Experimental y Salud Publica, 33(3), 478-488. https://doi.org/10.17843/ rpmesp.2016.333.2335

Santos, K. O. B., Araújo, T. M. D., Pinho, P. D. S., \& Silva, A. C. C. (2010). Avaliação de um instrumento de mensuração de morbidade psíquica: estudo de validação do Self-Reporting Questionnaire (SRQ-20). Revista Baiana de Saúde Publica, 34(3), 544-60. http://files.bvs.br/upload/S/0100-0233/2010/ v34n3/a1881.pdf

Schonfeld, I. S. (1996). Relation of negative affectivity to selfreports of job stressors and psychological outcomes. Journal of Occupational Health Psychology, 1, 397-412. https://doi. org/10.1037/1076-8998.1.4.397

Shattel, M, Apostolopoulos, Y., Collins, C., Sonmez, S., \& Fehrenbacher, C. (2012). Trucking organization and mental health disorders of truck drivers. Issues in Mental Health Nursing, 33(7), 436-444. https://doi.org/10.3109/01612840. 2012.665156

Shattell, M., Apostolopoulos, Y., Sonmez, S., \& Griffin, M. (2010). Occupational stressors and the mental health of truckers. Issues in Mental Health Nursing, 31(9), 561-568. https://doi.org/10 .3109/01612840.2010.488783

Silva, J. L. L. D., Moreno, R. F., Soares, R. D. S., Almeida, J. A., Daher, D. V., \& Teixeira, E. R. (2017). Prevalência de transtornos mentais comuns entre trabalhadores marítimos do Rio de Janeiro. Revista de Pesquisa: Cuidado é Fundamental Online, 9(3), 676-681. https://doi.org/10.9789/21755361.2017.v9i3.676-681

Silva-Junior, J. S. D., \& Fischer, F. M. (2014). Adoecimento mental incapacitante: Benefícios previdenciários no Brasil entre 20082011. Revista de Saúde Pública, 48(1), 186-190. https://doi. org/10.1590/S0034-8910.2014048004802

Silva, L. G. D., Luz, A. A. D., Vasconcelos, S. P., Marqueze, E. C., \& Moreno, C. R. D. C. (2016). Vínculos empregatícios, condições de trabalho e saúde entre motoristas de caminhão. Revista Psicologia Organizações e Trabalho, 16(2), 153-165. https:// doi.org/10.17652/rpot/2016.2.675

Stansfeld, S. A., Fuhrer, R., \& Head, J. (2011). Impact of common mental disorders on sickness absence in an occupational cohort study. Occupational \& Environmental Medicine, 68(6), 408413. https://doi.org/10.1136/oem.2010.056994

Ulhôa, M. A., Marqueze, E. C., Lemos, L. C., Silva, L. G. D., Silva, A. A., Nehme, P., \& Moreno, C. R. D. C. (2010). Distúrbios psíquicos menores e condições de trabalho em motoristas de caminhão. Revista de Saúde Pública, 44(6), 1130-1136. https:// doi.org/10.1590/S0034-89102010000600019

Van der Beek,A. J. (2012). World at work: Truck drivers. Occupational \& Environmental Medicine, 69(4), 291-295. https://doi. org/10.1136/oemed-2011-100342

World Health Organization. (2017). Depression and other common mental disorders: Global health estimates. Division of Mental Health. http://www.who.int/mental health/management/ depression/prevalence_global_health_estimates/en/ 